\title{
ETIKA BISNIS ISLAM DALAM PENGELOLAAN BISNIS DI PESANTREN MUKMIN MANDIRI
}

Yogiswara Karishma W

Mahasiswa Program Studi S1 Ekonomi Islam-Fakultas Ekonomi dan Bisnis-Universitas Airlangga Email :karishma_ogis@yahoo.com

Tika Widiastuti

Departemen Ekonomi Syariah-Fakultas Ekonomi dan Bisnis-Universitas Airlangga Email : tika.widiastuti@feb.unair.ac.id

ABSTRACT:

This research is aimed to determine the Islamic Business Ethics in business management at Pesantren Mukmin Mandiri Sidoarjo. Pesantren Mukmin Mandiri is one of pesantren based on agrobusiness and agro-industry which graduates entrepreneurs every year.

This research used the qualitative research method and case study as the strategy. Data collection was done by interviewing and observing the research object directly. The qualitative explanatory was used as the technique of analysis by explaining the results of the interviews and of the direct observations.

The results of The analysis showed that the business ethics of Islam are in some way and going well in business management in schools independent believer, it can be seen from the implementation of restrictions on the business that is concerned with the students.

Keywords: business ethics islam, limits, management of businesses, pesantren Mukmin Mandiri

\section{PENDAHULUAN}

\section{Latar Belakang}

Bekerja adalah salah satu perintah dalam agama Islam.Bekerja merupakan salah satu bagian dari usaha, dimana usaha adalah salah satu upaya untuk mendapatkan rezeki yang telah digariskan Allah SWT.

Allah menjelaskan barang siapa yang bekerja atau berusaha maka rezeki itu akan turun sepertia apa yang telah ia usahakan. Usaha dan rezeki memilki keterikatan yang tidak terbatas, artinya usaha akan mendapatkan rezeki, jika tidak berusaha maka rezeki juga tidak akan diberikan oleh Allah SWT. Bekerja atau usaha memiliki keanekaragaman, diantaranya adalah dengan menjalankan sebuah bisnis adalah salah satu pekerjaan yang digemari oleh Rasulullah.Rasulullah adalah seorang pebisnis hebat pada masanya yang menerapkan nilai-nilai Islam dalam menjalankan bisnisnya. Rasulullah juga menggunakan berbagai macam strategi bisnis untuk menyukseskan bisnis sang istri, Khadijah ra. Strategi bisnis yang diemban Rasulullah SAW mengandung nilai-nilai transparan, kejujuran, dan bersifat flexibel.Hal-hal yang diusung oleh Rasulullah itulah yang mampu menciptakan sebuah nilai ekonomi Islam yang terarahkan.

Seorang pebisnis muslim dalam menjalankan usahanya tentu harus memiliki etika, tidak hanya memandang hasil secara fisik atau profit secara materi tetapi juga harus memperhatikan unsur ibadah yang diusung dalam berbisnis. Allah menjelaskan dalam firman-Nya yang berbunyi :

1) Jurnal ini merupakan bagian dari skripsi yang ditulis oleh Yogiswara Karishma W. NIM: 040810380, yang diuji pada bulan 8 Agustus 2016 


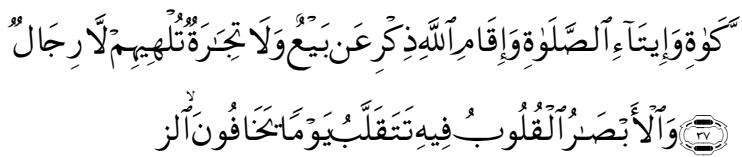

rijaalun laa tulhiihim tijaaratun walaa bay'un 'an dzikri allaahi waiqaami alshshalaati wa-iitaa-i alzzakaati yakhaafuuna yawman tataqallabu fiihi alquluubu waal-abshaaru

"laki-laki yang tidak dilalaikan oleh perniagaan dan tidak (pula) oleh jual beli dari mengingati Allah, dan (dari) mendirikan sembahyang, dan (dari) membayarkan zakat. Mereka takut kepada suatu hari yang (di hari itu) hati dan penglihatan menjadi goncang."( Qs. An-Nur 37 )

Ayat diatas menjelaskan bahwa seorang yang sedang melakukan kegiatan jual beli ( pebisnis ) diwajibkan memiliki keseimbangan dalam hidupnya. Seorang pebisnis muslim dilarang untuk berat sebelah, artinya pebisnis muslim wajib menyeimbangkan antara kegiatan duniawi ( berbisnis) dan kegiatan akhirat ( beribadah ), tidak boleh melalaikan shalat wajib, tidak lupa dalam zakat dan amal lainnya serta yang paling pokok adalah tidak meninggalkan etika-etika bisnis yang dicontohkan oleh Rasulullah SAW. Etika-etika bisnis Islam tersebut merupakan bagian penyeimbang kegiatan bisnis para pebisnis muslim agar apa yang ia kerjakan mendapat berkah, ridha dari Allah SWT serta profit berupa rezeki yang melimpah.

Keberhasilan bisnis Rasulullah berpegang kepada empat hal yakni shidiq artinya Nabi Muhammad selalu jujur dalam memasarkan dagangannya, beliau selalu menginformasikan dengan akurat barang yang dibawanya. Kedua beliau mengusung sifat amanah atau dapat dipercaya, Rasulullah selalu mengembalikan apa yang bukan menjadi haknya. Ketiga adalah adalah fathonah dimana Rasulullah mampu memahamami dan menghayati apa yang menjadi tugasnya sebagai pebisnis. Sebuah perusahaan bisa menggunakan sifat ini untuk mengembangkan inovasi dan strategi pemasaran yang baik.Terakhir adalah tabgligh yang artinya komunikatif dan argumentatif.Rasulullah mampu menyampaikan keunggulan produknya dengan menarik dan tepat sesaran tanpa meninggalkan unsur yang beliau pegang yaitu kejujuran.

Etika bisnis dalam Islam adalah sejumlah perilaku etis bisnis (akhlaq al Islamiyah) yang dibungkus dengan nilainilai syariah yang mengedepankan halal 
Karishma W, et al/Jurnal Ekonomi Syariah Teori dan Terapan Vol. 4 No. 6 Juni 2017: 464-477; ETIKA BISNIS ISLAM DALAM PENGELOLAAN BISNIS DI PESANTREN MUKMIN MANDIRI

dan haram. Jadi perilaku yang etis itu ialah perilaku yang mengikuti perintah Allah dan menjauhi larangnya.Dalam Islam etika bisnis ini sudah banyak dibahas dalam berbagai literatur dan sumber utamanya adalah Al-Quran dan sunnaturrasul.Pelaku-pelaku

bisnis diharapkan bertindak secara etis dalam berbagai aktivitasnya.Kepercayaan, keadilan dan kejujuran adalah elemen pokok dalam mencapai suksesnya suatu bisnis di kemudian hari ( Amalia. 2013:3 ).

Pasar akan hancur jika pemilihan strategi pemasaran tidak memperhatikan etika-etika serta norma yang ada. Islam menghendaki pebisnis yang merangkul para pesaing bisnis bukan untuk menjatuhkan.Kalimat Fastabiqhul Khairat merupakan slogan dalam Islam yang mengajarkan untuk berlomba dalam kebaikan, begitu pula dalam berbisnis, diperintahkan melakuakan segala bentuk strategi pemsaran yang sesuai dengan konsep Islam.Strategi pemasaran syariah adalah salah satu obat bagi dunia bisnis saat ini, baik mulai dari lapisan bawah hingga perusahaan besar.
Pesantren adalah salah satu lembaga pendidikan yang tertua di Indonesia.Pesantren memiliki peran besar terhadap keberlangsungan pengembangan dan revitalisasi mental dan akhlaq para generasi muda Indonesia.Pondok pesantren memiliki fungsi meningkatkan kecerdasan, baik ilmu pengetahuan maupun moral.Pada eksistensinya, pesantren memiliki peran lebih pada fungsi control moral dan nilai agama.Fungsi ini mampu menjadikan pesantren sebagai pilihan utama masyarakat dalam menghadapi globalisasi.( Jamaluddin, 2012:128 )

\section{Rumusan Masalah}

Berdasarkan uraian latar belakang diatas, maka rumusan masalah yang diajukan dalam penelitian ini adalah : Bagaimana implementasi etika bisnis Islam dalam pengelolaan bisnis di pesantren Mukmin Mandiri Sidoarjo?

\section{LANDASAN TEORI}

\section{Konsep Bekerja dalam Islam}

Bekerja adalah suatu kegiatan yang digolongkan muamalah ( ibadah ). Islam menganjurkan kepada setiap umatnya untuk bekerja.Bekerja ditujukan untuk memperoleh rezeki yang telah digariskan Allah SWT. Bekerja dengan 
tujuan mendapatkan penghasilan yang besar dan kehidupan yang lebih layak diperbolehkan dalam Islam, tetapi bekerja yang seperti apa dan bagaimana yang diperbolehkan dalam Islam. Hal ini menyangkut dengan ketentuan dan hukumnya selain itu kerja seperti apa dan bagaiman juga akan mempengaruhi terhadap pekerja itu sendiri.

Al-Quran menjelaskan dalam sebuah ayat yang berbunyi :

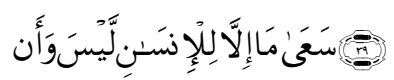

Wa alaysa lilinsani illa ma saAAa

Dan bahwasannya seorang manusia tiada memperoleh selain apa yang telah diusahakannya ( An Najm 53: 39 )

Rezeki oleh manusia seringkali hanya dimaknai sebatas materi padahal rezeki itu meliputi segala sesuatu yang kita nikmati.Rezeki materi baik non materi, kehidupan, nafas, kesehatan, jabatan, kekayaan, dan masih banyak lagi. Rezeki sendiri dapat diperoleh dengan ikhtiar yakni dengan bekerja, seperti yang telah dijelaskan oleh ayat Al-Quran sebelumnya bahwa manusia tidak akan memperoleh apapun jika bukan dari usahanya sendiri. Bekerja sendiri memiliki banyak sekali keragaman dan profesi.Salah satu diantaranya adalah sebagai seorang pebisnis.Pebisnis adalah profesi Rasulullah SAW semasa hidupnya, dimana menjadi pebisnis adalah salah profesi favorit Nabi Muhammad SAW disamping mengemban amanah sebagai Rasulullah.Bisnis memiliki banyak sekali keistimewaan sehingga nabi sendiri gemar sekali berdagang.

\section{Bisnis menurut Presepektif Islam}

Madura ( 2007: 5 ) mengatakan bahwa suatu bisnis ( atau perusahaan ) adalah usaha yang menyediakan produk atau jasa yang diinginkan oleh pelanggan. Menurut departemen tenaga kerja AS, lebih dari 800.000 bisnis diciptakan di AS setiap tahunnya.

Hal diatas menjelaskan bahwa secara umum bisnis adalah suatu motif manusia untuk mendapatkan sebuah keuntungan secara material ( laba ) disamping fungsinya yakni memenuhi dan memuaskan pelanggan. Lalu bagaimana Islam memandang bisnis itu sendiri. Islam menjelaskan bahwa bisnis adalah serangkaian aktivitas dalam berbagai bentuk yang tidak dibatasi jumlah kepemilikan hartanya ( barang/jasa ) termasuk profitnya, namun dibatasi dalam cara perolehan dan pendayagunaan hartanya ( ada aturan halal dan haram ).

Bisnis Islam adalah salah satu bentuk implementasi ajaran Islam yang rahmatan lil Alamin yang bersifat menyeluruh.Bisnis Islam menekanakan bahwa kepemilikan, pemanfaatan, dan pelaksanakannya bisa dilakukan oleh siapapun tanpa memandang mereka siapa.Disamping itu, bisnis juga merupakan salah satu ajaran aplikatif tentang pelaksanaan manusia sebagai khalifah di muka bumi yang bertujuan memakmurkan bumi berdasarkan tuntunan Allah SWT.

\section{Landasan Binis Islam}


Islam memiliki beberapa landasan dalam kegiatan berbisnis. Hal ini diatur dalam Al-Quran juga dalam kegiatan yang telah dicontohkan oleh Rasulullah SAW. Landasan bisnis Islam diantaranya adalah tauhid, keseimbangan dan keadilan kemudian ada pertanggung jawaban dan yang terakhir adalah kehendak bebas. Landasan tauhid adalah dimana seorang pebisnis muslim wajib menyertakan niatnya dalam berbisnis karena Allah SWT. Pebisnis muslim memahami bagaimana keikutsertaan Allah dalam mengatur dan menjalankan bisnisnya. Kedua landasan keseimbangan dan keadilan adalah dimana seorang pebisnis muslim diwajibkan menyeimbangkan kegiatan duniawi dan akhiratnya, tidak boleh memisahkan keterikatan dua kegiatan tersebut. Allah berfirman dalam Al-Quran :

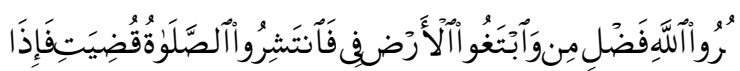

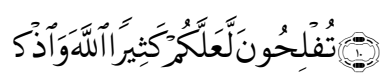

Faitha qudiyati alssalatu faintashiroo fee alardi waibtaghuu min fadli Allahi waothkuruu Allaha kathiiran laAAallakum tuflihuuna

Apabila telah diturunkan shalat, maka bertebaranlah kamu di muka bumi; dan carilah karunia Allah ( rezeki ) dan ingatlah Allah banyak-banyak supaya kamu beruntung ( Al-Jumuah, 62:10).
Ayat diatas menjelaskan dimana seorang muslim diwajibkan untuk bekerja, berusaha dan bertebaran dimuka bumi untuk mencari profit, keuntungan, laba dalam segi materi maupun non materi. Ayat tersebut meletakkan kata shalat sebelum bertebaran dimuka bumi, artinya kegiatan akhirat harus didahulukan sebelum melakukan kegiatan duniawi yang tujuannya sama yakni mencari ridha Allah SWT.

Dalam ajaran ekonomi Islam semua jenis transaksi dalam bisnis didasar oleh prinsip-prinsip yang menjadi pijakan dan patokan. Prinsip dasar dalam bisnis Islam adalah prinsip ilahiyah ( prinsip ketuhanan ). Semua aktivitas termasuk bisnis yang dilakukan bukan hanya pada dimensi duniawi semata, yang berarti berkaitan untung rugi saja.Lebih dari itu, berbisnis dalam Islam adalah manifestasi dari kehambaan manusia kepada Sang Khalik melalui amal sosial, yakni berbisnis.Berbisnis merupakan aktivitas antar manusia yang saling membutuhkan sedang keuntungannya adalah efek dari saling membantu tersebut. Prinsip ketuhanan ini tidak hanya akan menjadikan bisnis berjalan dengan cara yang benar sesuai aturan syariat, tapi bisnis juga akan lapang dan menyenangkan tanpa rasa takut tersaingin atau tidak mendapat keuntungan yang sama.

Islam memberikan kebebasan kepada pemeluknya untuk melakukan usaha (bisnis) namun dalam Islam 
ada beberapa prinsip dasar yang menjadi etika normatif yang harus ditaati ketika seorang muslim akan dan sedang menjalankan usaha, diantaranya adalah :

1. proses mencari rezeki bagi seorang muslim merupakan suatus tugas wajib

2. rezeki yang dicari haruslah rizki yang halal

3. bersikap jujur dalam menjalankan usaha

4. semua proses yang dilakukan dalam rangka mencari rezeki haruslah dijadikan sarana untuk mendekatkan diri kepada Allah SWT.

5. Bisnis yang akan dan sedang dijadikan sebagai sarana berprestasi secara fair dan sehat ( fastabikul al-khayrat )

6. Tidak boleh berpuas diri dengan apa yang sudah didapatkan

7. Menyerahkan setiap amanah kepada ahlinya, bukna kepada sembarang orang sekalipun keluarga sendiri.

Islam meletakkan garis panduan berdagang untuk menjamin keadilan menurut perintah Allah karena hukum bisnis tidak sama dengan pelaksanaan akidah yang memerlukan transformasi secara menyeluruh dan drastis seperti meruntuhkan berhala yang terdapat di Kabah sewaktu pembukaan kota Mekah. Bisnis dibolehkan selama tidak bertentangan dengan syariat.

\section{Landasan Bisnis dalam Islam}

( Anis, 1993:50 ). Islam menawarkan keterpaduan agama, ekonomi, dan sosial demi membentuk kesatuan. Atas hal inilah para pelaku bisnis dalam melaksanakan pekerjaannya harus menerapkan tiga hal : 1) tidak diskriminasi terhadap pekerja, penjual dan pembeli, mitra kerja atas dasar pertimbangan ras, warna kulit jenis kelamin atau agam, 2) Allah yang paling ditakuti dan dicintai.

Kedua adalah keseimbangan atau keadilan.Sering sekali terjadi pemilahan orientasi seorang pelaku bisnis dengan membedakan antara kehidupan dunia dan akhirat. Kehidupan dunia harus dikejar dengan cara keduniaan, sedangkan kehidupan akhirat diperoleh dengan aktivitas ibadah dalam arti sempit seperti shalat, puasa, zakat dan haji. Padahal Islam sendiri tidak membedakan kehidupan dunia dan akhirat secara terpisah sebab semua aktivitas dapat bernilai ibadah jika bertujuan mencari ridha-Nya yang dilandasi dengan aturanaturan yang telah disyariatkan Allah. Pada dasarnya ajaran Islam berorientasi pada terciptanya karakter manusia yang memiliki sikap dan perilaku yang seimbang dan adil dalam konteks hubungan antara manusia dengan diri sendiri, manusia dengan orang lain ( masyarakat) bahkan manusia dengan Tuhan. Keseimbangan ini ditekankan oleh Allah dalam istilah Ummatan washatan atau yang dikenal sebagai manusia adalah umat yang memiliki kebersamaan, 
kedinamisan dalam gerak, arah, dan tujuannya serta memiliki aturan-aturan kolektif yang berfungsi sebagai penengah.Oleh karena itu, keseimbangan, kemoderatan merupakan prinsip etis mendasar yang harus ditetapkan dalam aktivitas maupun entitas bisnis.

Ketiga adalah kehendak
bebas.Berdasarkan konsep kehendak bebas, manusia memiliki kebebasan untuk membuat kontrak dan menepatinya ataupun mengingkarinya. Seorang muslim yang telah menyerahkan hidupnya pada kehendak Allah SWT, akan menepati semua kontrak yang telah dibuatnya, Allah swt memerintahkan kepada kaum muslim untuk memenuhi akad yang telah disepakati.

\section{Keempat adalah pertanggung} jawaban. Jika seorang pengusaha muslim berperilaku secara tidak etis, ia tidak dapat meyalahkana tindakannya pada persoalan tekanan bisnis ataupun pada kenyataan bahwa setiap orang juga berperilaku tidak etis. la harus bertanggung jawab atas tindakan yang ia lakukan.

\section{Konsep Etika Bisnis}

Etika bisnis merupakan ilmu yang dibutuhkan banyak pihak tetapi masih bersifat problematic dari sisi metodologis.llmu ini dibutuhkan untuk merubah performen dunia bisnis yang dipenuhi oleh praktek-praktek mal bisnis.Praktek mal bisnis adalah mencakup baik business crimes maupun tort, yakni business crimes sebagai perbuatan bisnis yang melanggar hukum pidana atau business tort sebagai perbuatan bisnis yang melanggar etika. (Suwantoro, 1990: 20-21)

Problem etika bisnis terletak pada kesangsian apakah moralitas mempunyai tempat dalam kegiatan bisnsi ( Keraf, 1997:49 ). Bisnis dan etika memiliki perbedaan dalam pengertian maupun penyelarasannya. Bisnis telah memiliki sistem dan struktur yang baku dalam dunianya, sedangkan etika adalah disiplin ilmu yang berisi patokan-patokan mengenai apa yang benar dan salah. Banyak kalangan menilai hal tersebut tidak seiring dengan sistem dan struktur bisnis.( Rahardjo. 1995: 2 ). Sebagian kalangan menganggap bahwa bisnis adalah kegiatan yang hanya berhubungan dengan keuntungankeuntungan semata dan mitos bahwa bisnis merupakan permainan saja.Dengan mitos tersebut, citra buruk bisnis seakan mendapat legitimasi.

Etika bisnis muncul ketika bisnis tidak lepas dari sorotan etika.Kegiatan menipu, mengurangi timbangan atau takaran adalah salah satu contoh konkrit adanya hubungan antara etika dan bisnis.Fenomena demikian yang membuat etika bisnis mendapat perhatian yang intesif sehingga menjadi kajian bidang ilmiah.

\subsubsection{Etika Bisnis prespektif Al-Quran}

Al-Quran lebih banyak membahas tema-tema tentang kehidupan manusia baik pada tataran individual maupun 
kolektivitas. Hal ini dibuktikan bahwa tema pertama dan terakhir dalam Al-Quran adalah mengenai perilaku manusia.(Rahman, 1992: 59).

Al-Quran dalam mengajak manusia untuk mempercayai dan mengamalkan tuntunan-tuntunannya dalam segala aspek kehidupan, seringkali menggunakan istilah-istilah yang dikenal dalam dunia bisnis seperti jual beli, untung-rugi dan sebagainya.(Shihab, 1997:4-5).Dijelaskan pula bahwa Al-Quran tidak memberikan peluang bagi manusia untuk menganggur dalam kehidupan dunia.Manusia juga diberi rasa dorongan untuk bekerja tetapi bekerja bukan hanya sekedar bekerja tetapi bekerja yang serius sehingga melahirkan keletihan. (Shihab

\section{Proposisi}

Penilitian ini didasarakan atas proposisi, penamaan etika bisnis Islam dan pengamalannya yang baik maka akan berdampak pada pengelolaan bisnis yang lebih baik.

\section{METODE PENELITIAN}

\section{Pendekatan Penelitian}

Metode penelitian yang digunakan dalam studi ini adalah metode kualitatif. Metode kualitatif adalah prosedur penelitian berupa studi kasus yang dipilih, bagaimana mengimplementasikannya dan apa hasilnya. Penelitian ini menggunakan menggunakan analisis studi kasus. Studi kasus adalah analisis yang cocok digunakan bilamana pokok pertanyaan suatu penelitian berkaitan dengan " bagaimana " dan " mengapa" dimana fokus penelitiannya terletak pada fenomena kontemporer.

\section{Ruang lingkup Penelitian}

Penelitian yang dimaksud adalah untuk menjawab rumusan masalah "Bagaimana implementasi etika bisnis islam dalam pengelolaan bisnis di pesantren Mukmin Mandiri Sidoarjo ? ". Rumusan masalah tersebut yang akan menjadi acuan bagi peneliti untuk menentukan ruang lingkup penelitian. Penelitian ini dilakukan pada Pesantren Mukmin Mandiri Sidoarjo dimana pesantren tersebut menggunakan basis agrobisnis dan agroindustri dalam mendidik santri-santrinya. Ruang lingkup penelitian ini terbatas pada bagaimana implementasi etika bisnis Islam dalam pengelolaan bisnis dan penerapan yang terdapat di pesantren Mukmin Mandiri Sidoarjo

\section{Jenis dan Sumber Data}

Penilitian ini menggunakan dua jenis data yaitu data primer ( utama) dan data sekunder ( penunjang Data primer diperoleh dengan wawancara langsung yaitu menanyakan sesuati kepada seorang informan. Sedangkan data sekunder dapat diperoleh melalui penelitian sebelumnya yang berupa arsip, laporan-laporan masa lalu, dan dokumen-dokumen yang relevan serta kajian pustaka yang berkaitan dengan permasalahan.

\section{Teknik Keabsahan Data}


Karishma W, et al/Jurnal Ekonomi Syariah Teori dan Terapan Vol. 4 No. 6 Juni 2017: 464-477; ETIKA BISNIS ISLAM DALAM PENGELOLAAN BISNIS DI PESANTREN MUKMIN MANDIRI

Pada tahap ini, peneliti meenghubungi pengasuh pesantren, Pak Muhammad Zakki untuk melakukan janjian wawancara.

Ketika di lokasi atau obyek penelitian

Setelah menyepakati janji yang telah ditentukan, maka peneliti datang ke pesantren yang berada di daerah waru, sidoarjo.Peneliti mengumpulkan data primer yang diperoleh dari observasi dan wawancara dengan pengasuh dan pengurus Pesantren Mukmin Mandiri Sidoarjo yang dilakukan secara terbuka dan berkala. Materi wawancara akan berkembang pada pertemuan berikutnya tetapi tetap terfokus dan mengarah pada topic penelitian sehingga mendapat informasi yang semakin lengkap dan akurat.

Untuk data sekunder, pengumpulan datanya berdasarkan pada kajian pustaka dan literatur mengenai etika bisnis islamdalam pengelolaan bisnis, yang diperoleh dengan membaca buku yang sudah dimiliki, membaca buku di ruang baca FEB atau mengakses e-book di internet.

\section{Teknik Analisis Data}

Penelitian ini menggunakan teknik analsisi kualitatif deskriptif.Analisis yang digunakan adalah mencocokan suatu teori dengan kajian proposisi yang telah ditemukan. Tujuan dari pencocokan tersebut adalah menganalisis data studi kasus dengan cara membuat suatu penjelasan ( naratif), dan menggambarkan (deskripsi) kasus yang bersangkutan dan membuktikan proposisi teoritis yang telah dibuat.

\section{HASIL ANALISIS DAN PEMBAHASAN}

etika bisnis maka dapat didefinisikan sebagai suatu tata cara yang dijadikan sebagai acuan dalam menjalankan kegiatan berbisnis. Dimana dalam tata cara tersebut mencakup segala macam aspek, baik dari individu, institusi, kebijakan, serta perilaku berbisnisPengertian Etika Bisnis dan Cara Penyusunannya. Untuk menyusun etika bisnis yang bagus, maka perlu diperhatikan beberapa hal berikut ini, yaitu tentang pengendalian diri, pertanggungjawaban sosial, menjadikan persaingan secara sehat, penerapan konsep yang berkelanjutan, dapat mempertahankan keyakinannya, konsisten dengan sebuah aturan yang sudah disepakati bersama, penumbuhan kesadaran serta rasa memiliki dengan apa yang sudah disepakati, menciptakan suatu sikap untuk saling percaya pada antar golongan pengusaha, serta perlu diadakannya sebagian dari etika bisnis untuk dimasukkan dalam hukum yang dapat berupa suatu perundangundangan.

Etika bisnis Islam adalah sebuah aturan-aturan dalam melaksanakan bisnis atau lebih sederhana larangan dan anjuran dalam berdagang.Al-quran menjelaskan bahwa seorang pedagang harus menyempurnakan timbangan tidak boleh mengurangi. 
Karishma W, et al/Jurnal Ekonomi Syariah Teori dan Terapan Vol. 4 No. 6 Juni 2017: 464-477; ETIKA BISNIS ISLAM DALAM PENGELOLAAN BISNIS DI PESANTREN MUKMIN MANDIRI

Orang yang beriman diperintahkan untuk bermurah hati, sopan dan bersahabat saat melakukan dealing dengan sesama manusia. Al Qur'an secara ekspresif memerintahkan agar kaum Muslimin bersifat lembut dan sopan manakala berbicara dengan orang lain sebagaimana yang tercantum dalam Surah Al Baqarah ayat 83 dan Surah Al Israa' ayat 53.

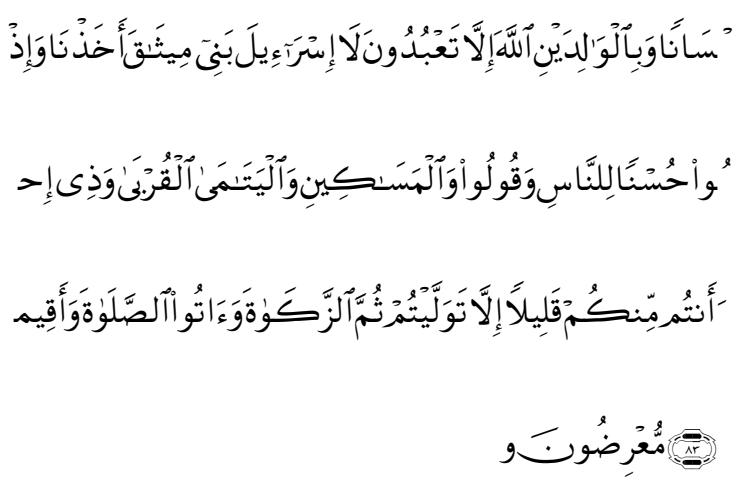

wa-idz akhadznaa miitsaaqa banii israaiila laata'buduuna illaa allaaha wabialwaalidayni ingsaanan wadzii alqurbaa waalyataamaa waalmas aakiini waquuluu lilnnaasi husnan waaqiimuv alshshalaata wagatuu alzzakaata tsumma tawallaytum illaa qaliilan minkum wa-antum mu'ridhuuna

"Dan (ingatlah), ketika Kami mengambil janji dari Bani Israil (yaitu): Janganlah kamu menyembah selain Allah, dan berbuat kebaikanlah kepada ibu bapa, kaum kerabat, anak-anak yatim, dan orang-orang miskin, serta ucapkanlah kata-kata yang baik kepada manusia, dirikanlah shalat dan tunaikanlah zakat. Kemudian kamu tidak memenuhi janji itu, kecuali sebahagian kecil daripada kamu, dan kamu selalu berpaling" ( QS. Albaqoroh 83 )

Bapak Heri menjelaskan bahwa etika bisnis Islam adalah batasan-batasan dalam melakukan kegiatan bisnis. Etika bisnis Islam di pesantren Mukmin Mandiri memiliki beberapa aspek diantaranya yaitu :

1. Tidak menjual Agama dalam Produk

Pesantren Mukmin Mandiri adalah pesantren berbasis wirausaha dengan konsen bisnis kopi. Pesantren yang dikenal sebagai tempat menuntu ilmu berbasis agama, tetapi hal ini tidak dijadikan alasan bagi pesantren Mukmin Mandiri untuk menjual agama dalam produk, artinya bukan karena kopi yang diproduksi oleh pesantren, dikelola santri maka kopi mahkota pasti membawa efek positif yang berbau agama.

2. Produksi harus halal Bapak heri mengatakan bahwa kopi yang diproduksi harus halal. Hal yang dimaksud adalah tidak hanya dari bahannya saja, tetapi cara pengelolaan, kualitas itu harus dijaga sehingga apa yang ditawarkan kepada konsumen sesuai dengan hasil di lapangan.

3. Tidak boleh over promise dalam menawarkan produk

Produk yang ditawarkan tidak boleh dipasarkan dengan berlebihan. Rasulullah tidak mencontohkan dalam memasarkan barangnya dengan perkataan atau hal yang berlebihan 
4. Tidak boleh menambah harga jual karena label doa

Banyak produk selain berlabel halal juga berlabel agama yang ditambahi harganya.Hal ini disampaikan bapak heri bahwa bukan karena kopi mahkota raja tersebut plus doa maka harga jualnya ditambah. Harga seharusnya seribu rupiah kemudian menjadi seribu lima ratus karena ada embel-embel doa. Bapak Heri menjelaskan bahwa kopi plus doa adalah cirri khas dari kopi santri tersebut, bukan sebagai embel-embel agar harga bisa dinaikkan atau sebagainya.

pesantren dengan yang lain. Para santri tidak hanya paham berwirausaha untuk kepentingan duniawi tetapi juga untuk kepentingan akhirat.

Etika bisnis adalah bentuk dari etika terapan. Etika bisnis merupakan aplikasi sebuah pemahaman tentang hal yang baik dan benar untuk beragam institusi, teknologi, transaksi, aktivitas dan usaha yang kita sebut bisnis. Pembahasan tentang etika bisnis harus dimulai dengan menyediakan kerangka prinsip-prinsip dasar pemahaman tentang apa yang dimaksud dengan istilah baik dan benar, hanya dengan cara itu selanjutnya seseorang dapat membahas implikasiimplikasi terhadap dunia bisnis. Etika dan Bisnis, mendeskripsikan etika bisnis secara umum dan menjelaskan orientasi umum terhadap bisnis, dan mendeskripsikan beberapa pendekatan khususterhadap etika bisnis, yang secara bersama-sama menyediakan dasar untuk menganalisis masalah-masalah etis dalam bisnis.

Bisnis dalam Islam memposisikan pengertian bisnis yang pada hakikatnya merupakan usaha manusia untuk mencari keridhaan Allah swt. Bisnis tidak bertujuan jangka pendek, individual dan sematamata keuntungan yang berdasarkan kalkulasi matematika, tetapi bertujuan jangka pendek sekaligus jangka panjang, yaitu tanggung jawab pribadi dan sosial dihadap masyarakat, Negara dan Allah swt.

Empat hal tersebut adalah ciri etika bisnis Islam yang diterapkan oleh pesantren Mukmin Mandiri. Selain keempat hal tersebut masih ada beberapa hal lain dalam etika bisnis Islam yaitu tindakan murah hati, selain bersikap sopan dan santun, adalah memberikan maaf dan berlapang dada atas kesalahan yang dilakukan orang lain, serta membalas perlakuan buruk dengan perilaku yang baik, sehingga dengan tindakan yang demikian musuh pun akan bisa menjadi teman yang akrab. Selain itu hendaknya seorang Muslim dapat memberikan bantuan kepada orang lain yang membutuhkan kapan saja ia dibutuhkan tanpa berpikir tentang kompensasi yang akan didapat.

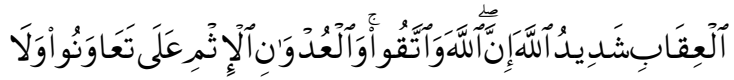


Karishma W, et al/Jurnal Ekonomi Syariah Teori dan Terapan Vol. 4 No. 6 Juni 2017: 464-477; ETIKA BISNIS ISLAM DALAM PENGELOLAAN BISNIS DI PESANTREN MUKMIN MANDIRI

walaa ta'aawanuu

'alaa al-itsmi

waal'udwaani

waittaque allaaha

inna allaaha syadiidu al'iqaabi

"...Dan tolong-menolonglah kamu dalam

(mengerjakan) kebajikan dan takwa, dan jangan tolong-menolong dalam berbuat dosa dan pelanggaran. Dan bertakwalah kamu kepada Allah, sesungguhnya Allah amat berat siksa-Nya" ( QS. Al-Maidah 2 ) Ketika membahas etika bisnis tentu saja tidak hanya sebuah batasan atau teori saja yang diungkap.Banyak aspek yang harus diterapkan dari nilai-nilai batasan tersebut agar etika bisnis Islam benarbenar terealisasikan dengan baik.Implementasi batasan-batasan dalam berbisnis seperti yang dikatakan bapak Heri di Pesantren Mukmin Mandiri diterapkan dalam langkah setiap pengelolaan bisnis kopi mahkota raja.

Penerapan empat hal diatas dalam setiap pengelolaan kopi memiliki poin penting bagi pesantren Mukmin Mandiri adalah semua hal tersebut ditujukan oleh santri dan berawal dari santri, demikian penjelasan pak Heri. Hal lain yang dengan menerapkan batasanbatasan dalam berbisnis atau disebut etika bisnis adalah agar mampu menyeimbangkan kebaikan dunia serta kebaikan akhirat.

茴

rabbanaaaatina fii

alddunyaahasanatan wafii al-aakhirati hasanatan waqinaa 'adzaaba alnnaari
"Ya Tuhan kami, berilah kami kebaikan di dunia dan kebaikan di akhirat dan peliharalah kami dari siksa neraka" ( Q.S Al-baqoroh 201 )

Ayat diatas adalah implementasi dari etika bisnis Islam oleh Pesantren Mukmin Mandiri, bahwa menjadi seorang Muslim tidak hanya mengejar duniawi yang berlebihan, tetapi menyeimbangkan antara urusan dunia dan akhirat, karena bermuamalah adalah suatu ibadah yang dilakukan secara real diluar kegiatan akhirat yang bersifat langsung seperti sholat, zakat, puasa dan haji. Kegiatan mengelola bisnis kopi tidak hanya mengedepankan tentang cara mendapat kekayaan duniawi saja, tapi merelevankan bagaimana kegiatan duniawi juga menjadi jembatan sebagai ladang pahala untuk bekal diakhirat kelak.

\section{Keterbatasan Penelitian}

Penilitian ini memiliki beberapa keterbatasan dan jauh dari kata sempurna. Keterbatasan penelitian ini adalah belum maksimal dalam menggambarkan etika bisnis islam secara luas dan lebih objektif dikarenakan hanya dilakukan pada satu pesantren saja. Kedua, keterbatasan informan yang ahli dibidangnya di pesantren mukmin mandiri tersebut.Ketiga, latar belakang pendidikan, serta karakter masing-masing informan sehingga peneliti memiliki keterbatasan dalam memperoleh informasi. 


\section{DAFTAR PUSTAKA}

Abdussalam, Yusuf. 2009. Bertanya Tuhan tentang Rezeki. Bantul: Media Insani

Afifuddin dan Beni A. Soebani. 2009. Metode Penelitian Kualitatif. Bandung : Pustaka Setia

Afzalurahman. 2000. Muhammad sebagai seorang pedagang

Agustino, Leo. 2008. Dasar-Dasar Kebijakan Publik. Bandung: Alfabeta

Al-Bukhari. 1987. al-Jami' ash-Shahih, Beirut : Dar Ibn Katsir

Arlina, Azti. 2010. Belajar bisnis kepada Khadijah

Amalia, Fitri. Implementasi Etika Bisnis Islam Pada Pedagang di Pasar Madinah Depok, UIN Syarif Hidayatullah. Jakarta

Al-Mawardi. 1995. Adab ad-Dunya wa adDin. Beirut: Dar al-Fikr,

Efendi, Agus. 2005. Revolusi Kecerdasan Abad 21. Bandung: Alfabet

Elfiky, Ibrahim. 2009. Terapi Berpikir

Positif, Terj. Khalifurrahman Fath dan M.

Taufik Damas.Jakarta: Zaman

Fauroni, Lukman. 2003. Rekronstuksi Etika Bisnis: Prespektif Al-Quran, sekolah tinggi ilmu syariah Yogyakarta, Volume 4, No.1

Harahap, S. Sofyan. 2011. Etika Bisnis dalam Prespektif Islam. Jakarta: Salemba empat

Hening, Cipta. 2010. Didalam diri ada Allah. Jakarta: PT Elex Media Komputindo

Hidayat, Mohammad. 2010. An Introduction to The Sharia Economic. Jakarta: Zikrul Hakim

Hidayatullah, Haris. Etika Bisnis dalam Prespektif Al-Quran: Upaya membangun bisnis yang Islami untuk menghadapi bisnis di masa depan, Fakultas Agama Islam Unipdu Jombang. Kartikasari, Jeany Megaputri. 2012. Dampak Pengalaman Karakter Amanah Bisnis Nabi Muhmmad SAW pada Kinerja Sosial KJKS BMT-UGT Sidogiri Surabaya. Surabaya: Fakultas Ekonomi dan Bisniss Universitas Airlangga
Kelana, Muslim. 2008. ABCDE Rasul : Muhammad SAW is a Great Enterpreneur. Bandung: Dinar Publisher

Kerajaan Arab Saudi.Al-Quran dan terjemahannya. Saudi Arabia

Kotler, Philip. 2004. Dasar-Dasar Pemasaran Jilid I. Jakarta: Prenhallindo.

Kotler, Philip. 2008. Dasar-Dasar Pemasaran Jilid II. Jakarta: Prenhallindo

Kurniawan, Anggoro Dwi. 2012. Analisis Pengaruh Produk, Promosi, Harga dan Tempat terhadap Keputusan Pembelian. Semarang. Fakultas Ekonomika dan Bisnis Universitas Diponegoro

Madjid, Nurcholis dkk.2002. Ensiklopedi Islam untuk Pelajar. Jakarta: PT. Ichtiar baru van hoeve

Madura, Jeff. 2007. Introduction to Bussiness: Pengantar bisnis edisi 4. Jakarta: Salemba Empat

Malahayati. 2010. Rahasia Sukses Bisnis Rasulullah. Yogyakarta:Jogja great! Publisher

Manullang, M.2006. Dasar-Dasar Manajemen.Jakarta:Ghalia Indonesia

Mullins John et.al dan Orville C. Wakler, JR. 2010.Marketing Management: A strategic.Decision-Making Aprroach. Seven Edition. New York: McGraw-Hill

Nawatri, Sri.2010. Etika Bisnis Islam Prespektif Islam, Fakultas Ekonomi Universitas Stikubank Semarang, Volume 9, No 1

Orgianus, Yan. 2012. Moralitas Islam dalam Ekonomi \& Bisnis. Bandung: Marja

Pasiak, Taufik. 2008. Revolusi IQ/EQ/SQ Menyingkap Rahasia Kecerdasan Berdasarkan Al-Quran dan Neurosains Mutakhir, Bandung: Mizan Pustaka

Permana, Aji Putra Setya. 2013. Kesesuaian Pengelolaan Bisnis Secara Islam Pada Hotel Syariah ( studi kasus pada hotel sofyan Jakarta ).Fakultas Ekonomi dan Bisnis Universitas Airlangga.

Rokan, Mustafa Kamal. 2013. Bisnis ala nabi: teladan Rasulullah Saw dalam bisnis. Yogyakarta: PT. Bentang Pustaka

Ryandita, Rr. Anis. 2013. Key success Faktor Pebisnis Muslim Pemilik Parahita Diagnostic Center Surabaya. Surabaya: Fakultas Eknomi dan Bisnis Universitas Airlangga 
Sulaiman, Zakaria dan Aizudinur Zakaria. 2010. Jejak Bisnis Rasullah. Jakarta: PT. Mizan Publika

Sumarni, Murti dan John Soeprihanto. 2005. Pengantar Bisnis ( Dasar-Dasar Ekonomi Perusahaan). Yogyakarta: Liberty Yogyakarta

Saleh, Muwafik. 2009. Bekerja dengan hati Nurani. Jakarta: Penerbit Erlangga

Suprajitno, Aribowo dan Sri Bawono. 2009. Kecerdasan Entrepreneur. Jakarta. PT. Elex Media Komputindo.

Suyanto, M. 2007. Smart in Entrepreneurship: Revolusi Strategis Mengubah Proses Bisnis untuk Meledakan Perusahaan.Yogyakarta: C.V Andi Offset

Syakir, Sula Muhammad dan Hermawan Kertajaya. 2006. Syariah Marketing. Bandung: Pustaka Mizan

Sya'rawi, M.Mutawalli. Rezeki

Usman, Husaini. 2004. Manajemen: Teori, Praktek, Dan Riset Pendidikan. Jakarta: Bumi Aksara

Yin, Robert K. 2011 .Studi Kasus Desain dan Metode.Jakarta. PT. Raja Grafindo Persada

Yusanto.Menggagas Bisnis Islam www.mukminmandiri.com www.kompasiana.com www.syariahbisnis.com 